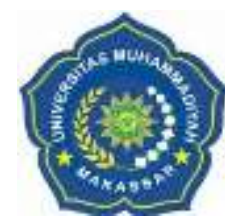

www.unismuh.ac.id
Jurnal Equilibrium Pendidikan Sosiologi

Vol V Mei No. 12017

\title{
Stratifikasi Sosial dalam Budaya A'matoang Masyarakat Turatea Kabupaten Jeneponto
}

\author{
Syarifuddin \\ Program Studi Pendidikan Sosiologi FKIP Universitas Muhammadiyah Makassar \\ syarifuddin@unismuh.ac.id
}

\begin{abstract}
.
This study aims to describe the culture of A'matoang and the form of social stratification in A'matoang Culture of Turatea people of Jeneponto Regency. Technique of taking informant which used in this research is Purposive sampling based on criterion which have been determined by researcher. Number of informants as many as 15 people aged 25-60 years. Data collection techniques used observation, interview, documentation and participatory methods. The result of the research shows that: (1) A'matoang culture is a series of marriage process, has meaning giving or giving in the form of goods such as clothes, sarong, songkok and veil to mother-in-law to the father-in-law of the men. (2) The form of social stratification in A'matoang cultures of society includes the large number and luxury of pa'matoang which means high social status, whether it is measured from the wealth possessed or from the nobility or karaeng lineage.
\end{abstract}

Keywords: Stratification, Culture, A'matoang

Abstrak. Penelitian ini bertujuan untuk mengambarkan budaya A'matoang dan wujud stratifikasi Sosial dalam Budaya A'matoang masyarakat Turatea Kabupaten Jeneponto. Teknik pengambilan informan yang digunakan dalam penelitian ini adalah secara Purposive sampling berdasarkan kriteria yang telah ditentukan peneliti. Jumlah informan sebanyak 15 orang yang berusia 25-60 tahun. Teknik pengumpulan data menggunakan metode observasi, wawancara, dokumentasi dan partisipatif. Hasil penelitian menunjukkan bahwa: (1) Budaya A'matoang merupakan rangkaian proses perkawinan, memiliki makna memberi atau pemberian berupa barang seperti pakaian, sarung, songkok dan kerudung kepada mertua yang dilakukan pihak perempuan kepada mertua pihak laki-laki. (2) Wujud stratifikasi sosial dalam budaya A'matoang masyarakat meliputi banyaknya jumlah dan mewahnya pa'matoang yang bermakna status sosial tinggi, baik itu diukur dari kekayaan yang dimiliki maupun dari golongan bangsawan atau keturunan karaeng.

Kata Kunci: Stratifikasi, Budaya, A'matoang 


\section{PENDAHULUAN}

Salah satu budaya yang mempunyai keanekaragamannya dalam melaksanakannya yaitu perkawinan. Perkawinan merupakan salah satu tahap dalam sepanjang siklus hidup manusia atau dalam ilmu antropologi disebut dengan stage $a$ long life cycle. Tahap-tahap yang ada disepanjang hidup manusia seperti masa bayi, masa penyapihan, masa anak-anak, masa remaja, masa pubertas, masa sesudah menikah, masa tua dan sebagainya (Koentjaraningrat, 1990:89). Perkawinan juga merupakan media budaya dalam mengatur hubungan antar sesama manusia yang berlainan jenis kelamin. Perkawinan bertujuan untuk mencapai suatu tingkat kehidupan yang lebih dewasa dan pada beberapa kelompok masyarakat kesukuan perkawinan dianggap sebagai alat agar seorang mendapat status yang lebih diakui ditengah kelompoknya (Koentjaraningrat, 1990:92). Dalam suatu adat perkawinan, setiap suku bangsa memiliki konsep dan aturan mengenai acara adat perkawinan. Tiap-tiap aturan acara perkawinan tersebut berbeda satu sama lainnya. Perbedaan ini berdasarkan bagaimana setiap suku bangsa memaknai dan menilai setiap rangkaian upacara adat perkawinan baik itu berdasarkan unsur-unsur budaya setiap suku bangsa, waktu dan biaya yang dibutuhkan, ataupun kepentingankepentingan dari pihak keluarga yang melangsungkan perkawinan. Salah satu budaya masyarakat Turatea Kabupaten Jeneponto pada acara perkawinan adalah $A^{\prime}$ matoang.

Tradisi atau budaya A'matoong adalah tradisi memberi atau pemberian kepada mertua yang dilakukan pihak perempuan kepada mertua pihak laki-laki. Budaya A'matoang sudah dilakukan sejak dulu oleh masyarakat Turatea yang merupakan salah satu rangkaian dalam proses adat perkawinan di Masyarakat Turatea Kabupaten Jeneponto. Dalam melaksanakan suatu upacara adat perkawinan perbedaan-perbedaan dalam proses sering ditemukan. Kelas sosial atau stratifikasi sosial dalam melakukan suatu upacara adat seperti perkawinan terlihat juga pada budaya masyarakat Turatea yang salah satunya pada budaya A'matoang. Dalam masyarakat Turatea ini terdapat perbedaan antara golongan atas, menengah dan bawah dalam melakukan tradisi A'matoang. Perbedaan tersebut terlihat pada jumlah barang yang diberikan kepada keluarga pihak laki-laki.

\section{METODE PENELITIAN}

Penelitian ini merupakan penelitian kualitatif yang bersifat deskriptif dengan memfokuskan penelitian pada "Stratifikasi Sosial dalam Budaya A'matoang". Jumlah informan dalam penelitian ini adalah 15 orang. Adapun yang menjadi kriteria dalam pemilihan informan adalah seorang ibu yang berumur 25-60 tahun, sehat, dan sudah mempunyai pengalaman dalam proses $A^{\prime}$ matoang ataupun yang menerima $P a^{\prime}$ matoang. Teknik yang digunakan untuk memperoleh data yang dibutuhkan dalam penelitian ini adalah metode observasi, wawancara, dokumentasi dan partisipatif. Teknik analisis data yang digunakan dalam penelitian ini adalah teknik analisis data kualitatif. Analisis data kualitatif adalah upaya yang dilakukan dengan jalan bekerja dengan data, mengorganisasikan data, memilah-milahnya menjadi satuan yang dapat dikelolah, mensitesiskannya, mencari dan menemukan pola, menemukan apa yang penting dan apa yang dipelajari dan memutuskan apa yang dapat diceritakan kepada orang lain. Teknik keabsahan data yang digunakan adalah triangulasi sumber, triangulasi teknik pengumpulan data, dan triangulasi waktu.

\section{PEMBAHASAN}

\section{Budaya A'matoang Masyarakat Turatea Kabupaten Jeneponto}

Konsep kebudayaan meliputi semua yang diperoleh dan dipelajari oleh manusia sebagai anggota masyarakat, kebudayaan mencakup cara atau pola berfikir, merasakan dan bertindak. Kebudayaan sangat berguna bagi manusia yaitu melindungi diri terhadap alam yang mengatur hubungan manusia dan sebagai wadah dari segenap perasaan dan pikiran manusia. Berkaitan dengan hal tersebut, dalam sistem pernikahan/perkawinan dikalangan masyarakat Turatea terdapat budaya A'matoang yang 
merupakan salah satu bagian dari prosesi adat pernikahan/perkawinan mereka. Dari hasil penelitian diketahui bahwa budaya A'matoang dilakukan setelah semua proses pernikahan/perkawinan dianggap terselesaikan. Waktu pelaksanaan budaya A'matoang ini merupakan aturan yang harus diikuti secara turun temurun oleh masyarakat Turatea, berarti hal ini mencerminkan sistem norma dalam suatu kebudayaan yang dianut oleh masyarakat.

Hal tersebut sesuai dengan Soejono Soekanto (1990:173) mengemukakan bahwa kebudayaan mengatur agar manusia dapat mengerti bagaimana seharusnya bertindak, berbuat, menentukan sikapnya kalau mereka berhubungan dengan orang lain. Dengan kata lain makhluk pribadi sekaligus makhluk sosial dimana sebagai pribadi manusia memiliki kebiasaan bagi dirinya sendiri. Dan sebagai makhluk sosial manusia membutuhkan orang lain dalam memenuhi kebutuhan hidupnya. Akan tetapi kita harus sadar didalam pengalaman hidup manusia, kebudayaan itu adalah bersifat universal, akan tetapi perwujudan kebudayaan mempunyai ciri-ciri yang khusus sesuai dengan situasi maupun lokasinya masing-masing. Masyarakat dan kebudayaan adalah dwi tunggal yang tak dapat dipisahpisahkan.

Ditambahkan lagi oleh pendapat menurut Paul. B. Horton dan Chester. L. Hunt (1991) dalam buku yang bejudul sosiologi jilid I, mengenai konteks kebudayaan dijelaskan bahwa kebudayaan non materi merupakan cikal bakal dari kebudayaan materi. Kebudayaan yang bersifat materi atau kebendaan muncul dari suatu gagasan, dan gagasan merupakan bagian dari kebudayaan non materi. Didalam bukunya tersebut dijelaskan bahwa kebudayaan sebagai suatu sistem norma, dalam suatu kebudayaan terdapat berbagai macam aturan yang mencerminkan pola kehidupan dan asusila masyarakat pendukung kebudayaan tersebut. Seperti kebiasaan, tata kelakuan, lembaga, hukum dan nilai yang dimiliki oleh masyarakat tersebut. Terkadang sistem norma yang ada dalam suatu kebudayaan mempunyai sifat memaksa, karena tidak selamanya kebudayaan itu sesuai dengan keinginan dan jalan pikiran setiap individu dalam masyarakat pendukung kebudayaan tersebut. Selanjutnya, dari hasil penelitian diketahui bahwa budaya A'matoang adalah pemberian atau penyerahan barang-barang yang diistilahkan Pa'matoang dari mempelai wanita kepada pihak mempelai laki-laki sebagai tanda terimah kasih yang atas uang panaik yang telah diberikan dan telah menikahinya. Serta budaya A'matoang juga bermaksud untuk mempererat silaturahmi antara kedua keluarga mempelai. A'matoang ini dilaksanakan setelah acara perkawinan telah selesai (masa sesudah perkawinan). A'matoang juga tidak hanya dilaksanakan oleh masyarakat Turatea, tetapi juga dilaksanakan oleh masyarakat Pallangga.

\section{Wujud Stratifikasi Sosial dalam Budaya A'matoang Masyarakat Turatea Kabupaten Jeneponto}

Semua manusia dapat dianggap sederajat. Akan tetapi, sesuai dengan kenyataan hidup kelompok-kelompok sosial, halnya tidaklah demikian. Pembedaan atas lapisan merupakan gejala universal yang merupakan bagian sistem lapisan sosial masyarakat. Staratifikasi sosial adalah gejala yang umum dan kuat dalam beberapa masyarakat didunia lain, khususnya peradaban dengan jumlah penduduknya yang besar dan heterogen. Masyarakat yang ada dalam stratifikasi sosial pada dasarnya adalah masyarakat yang penduduknya terbagi menjadi dua kelompok atau lebih. Dan kedudukan kelompok yang satu lebih tinggi atau lebih rendah jika dibandingkan dengan yang lain.

Perbedaan-perbedaan jelas terlihat dalam hak-hak, penghasilan, pembatasan dan kewajiban. Anggota kelompok yang dinilai lebih rendah akan cenderung lebih sedikit dari hak para anggota kelompok yang dinilai lebih tinggi. Kelompok ada kecenderungan tidak mendapat penghargaan yang sama serta mempunyai kewajiban yang kemungkinan besar sedikit lebih berat, meskipun anggota kelompok yang dinilai tinggi juga memiliki pembatasan dan kewajibannya sendiri yang khas untuk ditaati. 
Status sosial seseorang dalam masyarakat sebenarnya dapat dilihat melalui kehidupan sehariharinya yang merupakan ciri-ciri tertentu. Dalam sosiologi hal ini disebut status simbol. Status simbol tersebut tampak dalam cara berpakaian, pergaulan, tempat tinggal dan sebagainya. Hal ini sesuai dengan pendapat Clifford Geertz (dalam Achmad, 2005:288) mengemukakan suatu defenisi kebudayaan, yaitu (1) Suatu sistem keteraturan dari makna dan simbol-simbol, yang dengan makna dan simbol tersebut individu-individu mendefenisikan dunia mereka, mengekspresikan perasaanperasaan mereka, dan membuat penilaian mereka. (2) Suatu pola makna-makna yang ditransmisikan secara historis yang terkadang dalam bentuk simbol, yang melalui bentuk-bentuk simbol tersebut manusia berkomunikasi, memantapkan, dan mengembangkan pengetahuan mereka mengenai sikap terhadap kehidupan. (3) Suatu peralatan simbolik bagi mengontrol perilaku, sumber-sumber ekstrasomatik dari informasi. (4) Oleh karena kebudayaan adalah suatu sistem simbol, maka proses kebudayaan harus dipahami, diterjemahkan, dan diinterpretasi.

\section{KESIMPULAN}

1. Budaya A'matoang dilakukan setelah semua proses pernikahan/perkawinan dianggap terselesaikan. Budaya A'matoang adalah pemberian atau penyerahan barang-barang (diistilahkan Pa'matoang) dari mempelai wanita/perempuan kepada pihak mempelai lakilaki sebagai tanda terimah kasih atas uang panaik yang telah diberikan dan telah menikahinya. Serta budaya A'matoang juga bermaksud untuk mempererat silaturahmi antara kedua keluarga mempelai.

2. Wujud stratifikasi sosial dalam budaya A'matoang meliputi banyaknya jumlah dan mewahnya Pa'matoang bermakna status sosialnya tinggi, baik diukur dari kekayaan yang dimiliki maupun dari golongan bangsawan atau Karaeng. serta dalam budaya A'matoang menandakan barang-barang pemberian atau Pa'matoang dianggap sebagai simbol status atau kedudukan sosial seseorang dalam pelapisan sosial masyarakat Turatea Kabupaten Jeneponto.

\section{DAFTAR PUSTAKA}

[1] Ferawati. (2013). Pengertian Masyarakat. (http://ferawati1.blogspot.Com/2013/02 /pengertian-masyarakat-menurut-beberapaahli.html,diakses 16 April 2015).

[2] Horton, B Paul dan Hunt, Chester L. (1991). Sosiologi. Jakarta : Erlangga

[3] Narwoko dan Suyanto Bagon. (2011). Sosiologi Teks Pengantar dan Terapan. Jakarta : Kencana.

[4] Nurfadhilahtia94. (2013). Sifat-sifat stratifikasi Sosial. (http://nurfadhilahtia94.wordpress.com/2013/9/ 25/ penggolongan dan stratifikasi sosial di Indonesia. Diakses 20 april 2015.

[5] Soekanto, Soerjono. (1982). Memperkenalkan Sosiologi. Jakarta : PT. RajaGrafindo Persada.

[6] Soekanto,Soerjono. (1983). Beberapa Teori Sosiologi tentang Struktur Masyarakat. Jakarta : CV Rajawali.

[7] Soekanto,Soerjono. (2010). Sosiologi Suatu Pengantar. Jakarta : PT RajaGrafindo Persada.

[8] Sugiyono. (2011). Metode Penelitian Kuantitatif, Kualitatif dan R\&D. Bandung : Alfabeta.

[9] Tylor, E. B. (1924). Primitive Culture. New York : Brentano's.Vega. 2010. Stratifikasi Sosial. http://sosiologisosiologixavega.blogspot.com./2010/09/stratifika si sosial.html. diakses 26 Mei 2015

[10] Wandang, Septia Wandang. (2012). Unsur-unsur kebudayaan.

(http://integral8.blogspot.com/2012/05/7/unsure -kebudayaan-universal.ht.ml. diakses 20 April 2015)

[11] Wirawan. (2009). Kebudayaan. http://kebudayaan. wirawan.blogspot.com/2009/04/kebudayaan sunda. html. Diakses 26 Mei 2015. 